\title{
Letters
}

Website: www.bmj.com

Email: letters@bmj.com

\section{Consider validity, clinical relevance, and applicability of albumin for critically ill patients}

EdITOR-Because of a series of questions I have received about the current clinical use of human albumin in critically ill patients, I wish to clarify the message that I intended my editorial last week to convey. ${ }^{1}$

Given the current evidence as summarised by the Cochrane albumin reviewers group, ${ }^{2}$ the use of albumin does not need be stopped totally and immediately yet. The use of albumin in clinical practice has changed since the trials that were included in the systematic review. In the past few years the quality of albumin solutions has improved; contaminations and clinically relevant side effects are further limited. Although there is currently no evidence from clinical studies to support this, albumin given for the right indications at the right dose and infusion rate, with an optimal product being used, may be safe and effective and could lead to better outcomes than were found by the albumin reviewers group. Yet this still has to be shown. In situations where there are alternatives for albumin, such as crystalloids, and it is uncertain whether human albumin is the optimal treatment, comparative clinical studies should be undertaken to provide the evidence base for future decisions.

Advice to authors
We prefer to receive all responses electronically,
sent either directly to our website or to the
editorial office as email or on a disk. Processing
your letter will be delayed unless it arrives in an
electronic form.
We are now posting all direct submissions to
our website within 72 hours of receipt and our
intention is to post all other electronic
submissions there as well. All responses will be
eligible for publication in the paper journal.
Responses should be under 400 words and
relate to articles published in the preceding
month. They should include 55 references, in the
Vancouver style, including one to the BMJ article
to which they relate. We welcome illustrations.
Please supply each author's current
appointment and full address, and a phone or
fax number or email address for the
corresponding author. We ask authors to declare
any conflicts of interest.
Letters will be edited and may be shortened.
www.bmj.com
letters@bmj.com

My use of the word "halted" in the final sentence of my editorial-"the administration of albumin should be halted until ... the results of a high quality large clinical trial are available"-was intended to mean that clinicians should pause and consider the issues of validity, clinical relevance, and applicability as presented in the editorial before giving albumin to the next critically ill patient. ${ }^{1}$

Martin Offringa Consultant neonatologist Emma Children's Hospital, Academic Medical Centre, 1105 AZ Amsterdam, Netherlands

1 Offringa M. Excess mortality after human albumin admin-
istration in critically ill patients. BMJ 1998;317:223-4. (25 July.)

2 Cochrane Injuries Group Albumin Reviewers. Human albumin administration in critically ill patients: systematic albumin administration in critically ill patients: systematic
review of randomised controlled trials. BMJ 1998;317:23540. (25 July.)

\section{Tobacco link with insurance}

\section{Allied Dunbar is owned by BAT Industries and endorsed by BMA Services}

EDITOR-As a general practitioner and a member of the Labour party, I was disappointed by the British government's controversial plans to exempt Formula One motor racing from the proposed tobacco advertising ban. ${ }^{1}$ I am, however, heartened by the robust stance of the BMJ and BMA in their continued campaign to reduce the influence of the tobacco companies. ${ }^{23}$

I was thus surprised to discover, through an article in the magazine $G P{ }^{4}$ that $\mathrm{I}$ was being actively encouraged by BMA Services to invest in a company (Allied Dunbar) entirely owned by the tobacco giant BAT Industries. Fortunately, I learnt of this connection before taking out a life insurance policy with the company.

BMA Services provides independent financial advice to members of the BMA and their families. All financial products are vetted by BMA Services, and policies are recommended to their clients from a shortlist of financial institutions, the "best advice panel," which is reviewed every six months. Allied Dunbar and Zurich Life are two companies on the panel. BAT Industries have owned Allied Dunbar since the mid-1980s and it is considering a merger with Zurich Life. ${ }^{4}$ BMA Services is jointly owned by the BMA and Jardine Insurance Brokers, each of which receives $50 \%$ of the profits. It would therefore seem that it is not only the Labour party that has benefited from tobacco industry money.

In this day of ethical investment, representatives of BMA Services should at the very least have a duty to disclose all important ethical or material facts about the companies they are advising their clients to invest in. A proverb states: "He who lives in a glass house should not throw stones." Perhaps the BMA should consider whether Allied Dunbar (and Zurich Life if the proposed merger goes ahead) should remain on the list of companies recommended by BMA Services.

Charles Siderfin* General practice locum Diss, Norfolk IP22 IDP

*Charles Siderfin is a reformed smoker.

1 Kmietowicz Z. UK exempts motor racing from advertising ban. $B M J$ 1997;315:1251. (15 November.)

2 Delamothe T. UK government fails its first test on public health. BMJ 1997;315:1325-6.

3 Warden J. UK adheres to Formula One exemption. BMJ 1997;315:1397.

4 Andalo D. GP shock at tobacco link with insurance. GP 1997 Nov $7: 25$

\section{Reply from BMA Servies}

Our activities in financial planning are regulated by the Personal Investment Authority. One of the many requirements of this body is that we are able to show why we advise members to place their business with particular insurance companies and investment houses. Part of this process is the work that goes into the compilation of our "best advice panel" and the criteria that we use for selection. Much of the work related to the panel is undertaken for us by an external firm of consulting actuaries that specialises in providing information on subjects such as financial strength and past performance.

When this company considers these elements, along with many other aspects such as the flexibility and charging structure for each product, it then refines these into the panel that is used for different product areas. Allied Dunbar is a strong company financially, and some of its products rank highly for flexibility, competitiveness, and charges. It was for this reason that we have included, when appropriate, its products in our panel.

Our board meeting agreed that we should continue to recommend policies from Allied Dunbar when these were the most appropriate to meet the needs of individual members. However, we also recognise the concern expressed by Siderfin about the parentage of Allied Dunbar and the wish that individual members may have to avoid this particular company. 
Some months ago we altered the advice process that we undertake with individual members to point out the possibility that Allied Dunbar may be used as a preferred insurance company. If a member indicates that he or she does not wish us to recommend Allied Dunbar this is taken into account when the appropriate financial plan is drawn up.

We are aware of the proposed merger that may include Zurich Life. Although details of this merger have been announced, there is still a considerable amount of discussion taking place between the two companies; the resultant group, which is likely to include Allied Dunbar, Eagle Star, and Zurich Life, will not become operational until later in 1998. If this is the case then we would follow the same course of action for Zurich Life as for Allied Dunbar so that individual members are aware of the situation and can select an alternative insurer if appropriate.

John Winn Managing director

BMA Services, BMA House, London WC1H 9JH

\section{Passive smoking and heart disease \\ See Editorial by Smith Education and debate $p 333$}

Authors need to analyse the same data

EDITOR-In their meta-analysis Law et $\mathrm{al}^{1}$ reject results we published ${ }^{23}$ on environmental tobacco smoke and coronary heart disease, using data from the two large cancer prevention studies by the American Cancer Society and the national mortality followback survey. They reject our results because they disagree with our interpretation of data from other studies and because our analysis was funded by the tobacco industry (table 1).

By excluding our results Law et al discard 16280 relevant deaths from coronary heart disease with spousal smoking data and retain 6600 cases. They give no hint that their meta-analysis includes under a third of the available published data. The reasons for rejecting so many data should be considered. If Law et al believe we have misrepresented the data, they should analyse the same data from the American Cancer Society and the national mortality followback survey, and report their results.

Table 1 Data rejected by Law et al for their meta-analysis of spousal smoking and mortality from coronary heart disease in cancer prevention study I. ${ }^{2}$ Values are relative risks $(95 \%$ confidence intervals)

\begin{tabular}{|c|c|c|}
\hline $\begin{array}{l}\text { Spousal } \\
\text { smoking }\end{array}$ & Men* & Woment \\
\hline Ex & 0.95 (0.83 to 1.09 ) & 0.99 (0.93 to 1.05$)$ \\
\hline \multicolumn{3}{|l|}{ Current: } \\
\hline $1-19$ & 0.99 (0.89 to 1.09$)$ & 1.04 (0.97 to 1.12$)$ \\
\hline $20-39$ & 0.98 (0.85 to 1.13$)$ & 1.06 (0.98 to 1.15$)$ \\
\hline$\geqslant 40$ & 0.72 (0.41 to 1.28$)$ & 0.95 (0.78 to 1.15$)$ \\
\hline Ex or current & 0.97 (0.90 to 1.05$)$ & 1.03 (0.98 to 1.08$)$ \\
\hline Pipe/cigar & & $1.06(0.99$ to 1.14$)$ \\
\hline
\end{tabular}

${ }^{\star} 7758$ deaths among never smokers.

†7133 deaths among never smokers.

Table 2 Data rejected by Law et al for their meta-analysis of spousal smoking and coronary heart disease: case-control analysis of data from national mortality followback survey ${ }^{3}$

\begin{tabular}{|c|c|c|c|c|c|c|}
\hline \multirow[b]{2}{*}{$\begin{array}{l}\text { Spousal } \\
\text { smoking }\end{array}$} & \multicolumn{3}{|c|}{ Men } & \multicolumn{3}{|c|}{ Women } \\
\hline & Cases & Controls & $\begin{array}{l}\text { Relative risk } \\
(95 \% \mathrm{Cl})\end{array}$ & Cases & Controls & $\begin{array}{l}\text { Relative risk } \\
(95 \% \mathrm{Cl})\end{array}$ \\
\hline No & 378 & 783 & 1.0 & 459 & 969 & 1.0 \\
\hline Yes & 97 & 215 & 0.97 (0.73 to 1.28$)$ & 455 & 961 & 0.99 (0.84 to 1.16$)$ \\
\hline
\end{tabular}

Law et al's argument that our data from the second cancer prevention study disagree appreciably with data reported by Steenland et $\mathrm{al}^{4}$ is wrong. ${ }^{5}$ They incorrectly compare our results for ever-smoking spouse exposure with Steenland et al's results for current-smoking spouse exposure. Both studies present comparable results for subjects in the second cancer prevention study who are married to a current smoker. We calculate the relative risk for men to be 1.30 (95\% confidence interval 1.11 to 1.51$)$, for women 1.08 (0.89 to 1.32), and for both sexes combined 1.21 (1.07 to 1.37). These results are similar to those reported by Steenland et al (men 1.22 (1.07 to 1.40 ), women 1.10 (0.96 to 1.27$)),{ }^{4}$ which we have combined to give a relative risk of $1.16(1.05$ to 1.27) for both sexes.

Both sets of analyses report a barely significant association between environmental tobacco smoke and coronary heart disease in men, with a negative dose response. There is no significant association between spousal smoking and death from coronary heart disease in women, nor any sign of a dose response. Nearly twice as many women as men died of coronary heart disease in the second cancer prevention study, which makes the data for women particularly relevant to any meta-analysis.

Law et al's selective rejection of two thirds of the relevant data on environmental tobacco smoke and coronary heart disease raises additional questions about their interpretation of other data. We have noted significant publication bias in the pooled results on environmental tobacco smoke and coronary heart disease, for example. ${ }^{2}$ In reaching the opposite conclusion, Law et al ignore the significant association between study size and relative risk in the previously published spousal smoking studies as well as the significant difference between published and unpublished results on environmental tobacco smoke and coronary heart disease.

Maurice E LeVois* Senior scientist

Environmental Health Resources, PO Box 301, Tiburon, CA 94920, USA

Maxwell W Layard* Principal scientist

Layard and Associates, 2241 San Antonio Avenue, Alameda, CA 94501, USA

*M E LeVois and M W Layard hold outside consultancies with the Tobacco Institute, $1901 \mathrm{~K}$ Street, Washington, DC 20001, USA.

1 Law MR, Morris JK, Wald NJ. Environmental tobacco smoke exposure and ischaemic heart disease: an evaluation of the evidence. BMJ 1997;313:973-80. (18 October.)

2 LeVois ME, Layard MW. Publication bias in the environmental tobacco smoke/coronary heart disease epidemiologic literature Regul Toxicol Pharmacol 1995;21:184-91

3 Layard MW. Ischemic heart disease and spousal smoking in the national mortality followback survey. Regul Toxicol Pharmacol 1995:21:180-3.
4 Steenland K, Thun M, Lally C, Heath C Jr. Environmental tobacco smoke and coronary heart disease in the American Cancer Society CPS-II cohort Circulation 1996; 94:622-8.

5 LeVois ME, Layard MW. Letter to the editor re: Steenland LeVois ME, Layard MW. Letter to
et al. Circulation 1997;96:2086-7.

\section{Evidence on passive smoking and heart} disease needs re-evaluation

EDIToR-Law et al estimate that there is a $30 \%$ excess risk associated with spousal smoking on the basis of 6600 deaths from heart disease in 19 epidemiological studies. ${ }^{1}$ They distort the estimate by omitting results that are based on 15000 deaths from heart disease from the first cancer prevention study by the American Cancer Society. That study reported on spousal smoking and lung cancer in $1981 .^{2}$ Ten years ago the society told me that the study showed no effect on heart disease, but it never published its findings. Law et al reject published analyses of this study by LeVois and Layard ${ }^{3}$ because they are tobacco consultants and their analyses of the second cancer prevention study cited different relative risks from those reported by the American Cancer Society. Both analyses actually reported similar findings - a small decrease in risk for spouses who were former smokers and a small, nondose related, increase for spouses who were current smokers. The "difference" arose because LeVois and Layard followed precedent in concentrating on the index "spouse ever smoked" whereas the society emphasised results for "spouse current smoker." For the first cancer prevention study the risk was not increased for either index. If Law et al wish to reject analyses by tobacco consultants, they should have analysed the study themselves in order to avoid publication bias.

Law et al dismiss smoking misclassification bias as unimportant, ignoring recent evidence that smokers who deny smoking have a risk of heart disease that is 4.0 times higher $(95 \%$ confidence interval 1.8 to 9.1$)$ than that of smokers who admit to smoking. ${ }^{5}$ Their consideration of confounding relates only to a few of the many risk factors for heart disease.

Law et al say that the risks from passive smoking and smoking one cigarette a day are similar-an acute response to effects on platelets. This is based on a questionable backward linear extrapolation from data on risk by amount smoked (ignoring the known relative risk of 1.0 in non-smokers) and unjustified reliance on results from one single study of platelet aggregation in 10 subjects exposed to passive smoking in a hospital corridor.

This argument implies virtually no doseresponse relation between risk in non- 
Risk of heart disease in relation to spousal smoking, overall and by exposure level

\begin{tabular}{|c|c|c|c|c|c|c|}
\hline Study* & Sex & $\begin{array}{c}\text { Spousal } \\
\text { exposure } \\
\text { index }\end{array}$ & $\begin{array}{l}\text { Spousal smoking } \\
\text { relative risk† } \\
\text { (95\% confidence } \\
\text { interval) }\end{array}$ & Exposure levelsł & $\begin{array}{l}\text { Relative risk by } \\
\text { exposure level }\end{array}$ & $\begin{array}{c}\text { Significance } \\
\text { of trend§ }\end{array}$ \\
\hline \multicolumn{7}{|c|}{ Small studies (totalling 1815 cases) } \\
\hline Hirayama $^{18}$ & $\mathrm{~F}$ & Ever & $1.16(0.94-1.43)$ & $01-19 \geqslant 20$ & 1.001 .101 .31 & Yes \\
\hline Svendsen ${ }^{21}$ & M & Current & $1.61(0.96-2.71)$ & $01-19 \geqslant 20$ & 1.001 .201 .75 & No \\
\hline$\overline{\mathrm{He}^{22}}$ & $\mathrm{~F}$ & Ever & $1.50(0.63-3.60)$ & $01-20 \geqslant 21$ & 1.002 .306 .86 & Yes \\
\hline Hole $^{23}$ & $\mathrm{~F}$ & Ever & $1.65(0.79-3.46)$ & None Low High & 1.002 .094 .12 & Yes \\
\hline LaVecchia $^{27}$ & $\mathrm{M}+\mathrm{F}$ & Current & $1.21(0.57-2.53)$ & $01-14 \geqslant 15$ & 1.001 .131 .30 & No \\
\hline Tunstall-Pedoe ${ }^{29}$ & $\mathrm{M}+\mathrm{F}$ & Current & $1.37(1.07-1.75)$ & None Little Some Lot & 1.01 .21 .51 .6 & Yes \\
\hline$\overline{\text { Kawachi }^{32}}$ & $\mathrm{~F}$ & Current & $1.71(1.03-2.84)$ & $\begin{array}{l}\text { None Occasional } \\
\text { Regular }\end{array}$ & 1.001 .581 .91 & Yes \\
\hline$\overline{\text { Ciruzzij }^{33}}$ & $\mathrm{M}+\mathrm{F}$ & Ever & $1.43(0.90-2.00)$ & $01-20 \geqslant 21$ & 1.001 .271 .41 & Yes \\
\hline \multirow[t]{2}{*}{ Jackson $^{2}$} & M & Current & $1.06(0.39-2.91)$ & None Low High & 1.001 .300 .90 & No \\
\hline & $\mathrm{F}$ & Current & $3.75(1.15-12.19)$ & None Low High & 1.002 .107 .50 & Yes \\
\hline \multicolumn{7}{|c|}{ Large studies (totalling 20099 cases) } \\
\hline \multirow{2}{*}{$\begin{array}{l}\text { Cancer prevention } \\
\text { study } \mathrm{I}^{36}\end{array}$} & M & Current & $0.98(0.91-1.06)$ & $01-1920-39 \geqslant 40$ & 1.000 .990 .890 .72 & No \\
\hline & $\mathrm{F}$ & Current & $1.04(0.99-1.09)$ & $01-1920-39 \geqslant 40$ & 1.001 .041 .060 .95 & No \\
\hline \multirow{2}{*}{$\begin{array}{l}\text { Cancer prevention } \\
\text { study } \|^{31}\end{array}$} & M & Current & $1.22(1.07-1.40)$ & $01-1920 \geqslant 21$ & 1.001 .331 .171 .09 & No \\
\hline & $\mathrm{F}$ & Current & $1.10(0.96-1.27)$ & $01-192021-39 \geqslant 40$ & 1.001 .151 .070 .991 .04 & No \\
\hline \multirow[t]{2}{*}{ Layard $^{35}$} & M & Ever & $0.97(0.73-1.28)$ & $01-14 \quad 15-34 \geqslant 35$ & 1.000 .761 .070 .92 & No \\
\hline & $\mathrm{F}$ & Ever & $0.99(0.84-1.16)$ & $01-1415-34 \geqslant 35$ & 1.000 .851 .151 .06 & No \\
\hline
\end{tabular}

${ }^{*}$ Superscript numbers are references as given in Law et al ${ }^{1}$; only studies providing dose-response data are included. †Adjusted for age and confounding variables as far as presented by authors' estimates from data by level of exposure where appropriate.

$\ddagger$ Cigarettes/day except for Hole, Tunstall-Pedoe, Kawachi, and Jackson studies.

$\S$ Significance of positive trend at $\mathrm{P}<0.05$.

smokers and the extent of their exposure to environmental smoke, but Law et al never consider the dose-response data for passive smoking. The table shows that the results from the studies tend to fall into two groups-small studies reporting a moderate association and marked dose response and large studies reporting essentially no overall association or dose response. Neither group of results is consistent with the authors' theories.

The conclusion that passive smoking is an important cause of heart disease is premature. The data require further evaluation.

Peter Lee* Independent consultant in statistics and epidemiology

Sutton, Surrey SM2 5DA

*Peter Lee acts as a consultant to the tobacco industry.

1 Law MR, Morris JK, Wald NJ. Environmental tobacco smoke exposure and ischaemic heart disease: an evaluation

2 Garfinkel L. Time trends in lung cancer mortality among nonsmokers and a note on passive smoking.J Natl Cancer nonsmokers and a note
Inst 1981;66:1061-6.

3 LeVois ME, Layard MW. Publication bias in the environmental tobacco smoke/coronary heart disease
entican epidemiologic literature. Regul Toxicol Pharmaco 1995;21:184-91.

4 Steenland K, Thun M, Lally C, Heath C. Environmental tobacco smoke and coronary heart disease in the American Cancer Society CPS-II cohort. Circulation 1996;94:622-8.

5 Suadicani P, Hein HO, Gyntelberg F. Mortality and morbidity of potentially misclassified smokers. Int J Epidemiol 1997;26:321-7.

\section{$B M J$ should encourage open debate of available evidence}

EDITOR-As a principal scientist for Philip Morris I am aware that many readers will take the views expressed in this letter somewhat cynically. I appeal to readers' scientific objectivity and urge them to give due consideration to the issues raised below.
Law et al claim a potential relation between environmental tobacco smoke and ischaemic heart disease. ${ }^{1}$ They exclude the largest datasets available on the subject because they have "been published by Layard and LeVois, consultants to the tobacco industry." These data represent about twice as many ischaemic heart disease events as the other 19 studies added together. Law et al also mislead readers into believing that LeVois and Layard's analyses are inconsistent with the rest of the evidence. This is not the case: several of the 19 studies they selected for analysis report similar findings to those of LeVois and Layard. The results of one of the three studies published by LeVois and Layard ${ }^{2}$ are not inconsistent with the findings of an independent analysis of the same data by the American Cancer Society. ${ }^{3}$ A straightforward comparison shows mostly similarities-the only apparent differences are caused by the emphasis the different authors give to different reference groups.

This type of exclusion is symptomatic of the one-sided nature of the debate surrounding tobacco. There are other scientific flaws in Law et al's study. Unfortunately, even though many other scientists with no particular affection for the tobacco industry may share my views, few will speak out on this issue for fear of being branded as sympathisers of the industry. This is a disservice to science and erodes one of the fundamental tools of scientific investigation-the opportunity to debate.

Would the $B M J$ be willing to try to rectify some of the damage done to the scientific process and encourage correspondence from independent scientists whose views may be contrary to those of Law et al? Perhaps a direct invitation from the BMJ's editor would diminish the reluctance of such scientists to participate in the debate.

The issues raised by such papers have important implications for public health. It is therefore vital that they have a sound scientific basis. I believe that there are scientifically valid grounds for doubting the interpretation of the evidence given by Law et al. A fear of repercussions affecting anyone who voices an opinion that could be favourable to the tobacco industry seems to be preventing this process from taking place. We should all be striving to open up the debate, allowing sound scientific principles to decide on the best interpretation of the available evidence. I hope that the $B M J$ will play its part in facilitating this.

Ruth Dempsey Principal scientist, scientific affairs Philip Morris Europe, Scientific Affairs/EEMA Regions, 2003 Neuchâtel, Switzerland

1 Law MR, Morris JK, Wald NJ. Environmental tobacco smoke exposure and ischaemic heart disease: an evaluation of the evidence. BMJ 1997;315:973-80. (18 October.)

2 LeVois ME, Layard MW. Publication bias in the environmental tobacco smoke/coronary heart disease epidemiological literature. Regul Toxicol Pharmacol 1995;21:184-91

3 Steenland K, Thun M, Lally C, Heath Jr C. Environmental tobacco smoke and coronary heart disease in the American Cancer Society CPS-II cohort. Circulation 1997;95:2374-9.

\section{There must be better uses for money} spent on vilifying passive smoking

EDITOR-Law et al used a statistical method in a paper that was in press and assessed the increased risk of ischaemic heart disease due to confounding by low dietary intake of fruit and vegetables as only $3 \% .{ }^{1}$ Le Marchand et al calculated this as $13 \%$ (relative risk of 1.30 reduced to 1.15$)^{2}{ }^{2}$

It is well established that active smokers have lower intakes of fruit and vegetables and a higher intake of saturated and unsaturated fats, and that non-smokers who are exposed to environmental tobacco smoke share many of the dietary and lifestyle risk factors of smokers. ${ }^{3}$ Four studies have shown an inverse relation between exposure to environmental tobacco smoke and intake of $\beta$ carotene or fruit and vegetables, and a study of 4018 spouse pairs showed that the $\beta$ carotene concentrations were highly correlated $(r=0.46, \mathrm{P}=0.0001)$.

It is difficult to allow for confounding in two variables, such as diet and exposure to environmental tobacco smoke, that are correlated, ${ }^{4}$ but the relative risks for ischaemic heart disease in people with low serum vitamin concentrations (for example, 1.56 for low to high concentrations of $\beta$ carotene, and 1.96 for low to high concentrations of $\beta$ carotene and vitamin $\mathrm{C}^{5}$ ) are much higher than those reported for exposure to environmental tobacco smoke. The data from studies cited by Law et al did not allow for confounding by intake of saturated and unsaturated fats or by exercise, two elementary strong risk factors for ischaemic heart disease. $^{1}$

We know the score on active smoking, but surely the money spent on these attempts at vilifying passive smoking could be better spent in other areas of the NHS. 
I have no partisan interests. I am not funded by the tobacco companies, and this unit is funded out of my own pocket.

K W E Denson Director

Thame Thrombosis and Haemostasis Research Foundation, Thame, Oxfordshire OX9 3NY

1 Law MR, Morris JK, Wald NJ. Environmental tobacco smoke exposure and ischaemic heart disease: an evaluation of the evidence. BMJ 1997;315:973-80. (18 October.)

2 Le Marchand L, Wilkens LR, Hankin JH, Haley NJ. Dietary patterns of female nonsmokers with and without exposure to environment tobacco smoke. Cancer Causes Control 1991;2:11-6.

3 Thornton A, Lee PN, Fry J. Differences between smokers, ex-smokers, passive smokers and non-smokers. J Clin Epidemiol 1994;47:1143-62.

4 Leon DA. Failed or misleading adjustment for confounding. Lancet 1993;342:479-81.

5 Eichholzer M, Stahelin HB, Gey KF. Inverse correlation risk to develop cancer, ischaemic heart disease and strok risk to develop cancer, ischaemic heart disease and stroke respectively: 12 year follow up of the prospective Base
study. EXS 1999.62:398-410.

\section{Authors' reply}

EDITOR-We excluded the analyses of the tobacco industry consultants Layard and LeVois $^{12}$ for reasons given in our paper, ${ }^{3}$ and for the following reasons.

(1) They included never smokers married to former smokers (about half the "relevant deaths"), substantially inflating study size but diluting risk since the risk in former smokers, let alone that in their spouses, is not materially increased. ${ }^{4}$

(2) The correct analysis of the second cancer prevention study (never smokers married to current smokers) by Steenland, ${ }^{4}$ which we included, showed an increased risk of heart disease of $20 \%$ in men and women combined $(\mathrm{P}=0.006)$. LeVois and Layard confirmed this $(21 \%$ increase, $\mathrm{P}=0.003)$, but it was "washed out" in their main analysis by their inclusion of the large number of never smokers married to former smokers. In men these had an implausible significantly reduced risk, a surprising inconsistency from the Steenland analysis of the same data.

(3) Only LeVois and Layard analysed the first cancer prevention study. Their result in never smokers married to current smokers (relative risk 1.03) is statistically inconsistent $(\mathrm{P}=0.01)$ with their own result from the second cancer prevention study (1.21), which they did not point out. One must be right and the other wrong. The appropriate analysis is not to take an "average" of the first cancer prevention study and the others but to exclude the result that is inconsistent with all the others, which is what we did.

(4) In the national mortality followback survey-smoking histories on people who had died of lung cancer and their spouses were sought from relatives. This methodology has not been validated and is subject to substantial reporting error and dilution of effect.

Publication bias can be rejected; one must invoke some 300 unpublished studies to explain the association. ${ }^{3}$ Lee's cited fourfold difference in risk of heart disease between smokers who do and do not admit to smoking cannot reasonably be accepted when the difference in risk between genuine smokers and non-smokers is less than twofold. ${ }^{3}$ The published data in the large cohort studies of smoking and heart disease between $\mathrm{M}$, Stahelin $\mathrm{HB}$, Gey KI. Inverse correlation (figure 2 in our paper ${ }^{3}$ ) confirm a non-linear dose response. Evidence that low dose exposure to tobacco smoke has a pronounced effect on platelet aggregation comes not from one study but also from six experiments in 158 non-smokers who smoked one or two cigarettes. ${ }^{3}$

Dempsey's appeal for scientific objectivity is welcome; would that it were followed by her employers. As the tobacco industry has never acknowledged that active smoking causes heart disease or lung cancer, it cannot credibly comment on the lower dose exposure of passive smoking.

Denson believes that confounding, particularly with exercise and dietary fat, is important. Both are excluded by the negligible difference in serum cholesterol and blood pressure between non-smokers living and not living with smokers. ${ }^{3}$ In general, confounding is unlikely to explain most of the association because the factors have neither strong enough associations nor sufficient exposure differences to account for the $30 \%$ excess risk. For example, few older people in Western countries exercise sufficiently to reduce their risk by $30 \%$; it is unlikely that all non-smokers married to non-smokers (but none married to smokers) would exercise sufficiently.

M R Law Reader

J K Morris Senior lecturer

N J Wald Professor

Department of Environmental and Preventive

Medicine, Wolfson Institute of Medicine, St

Bartholomew's and The Royal London School of Medicine, London EC1M 6BQ

1 LeVois ME, Layard MW. Publication bias in the environmental tobacco smoke/coronary heart disease epidemiological literature. Regul Toxicol Pharmacol epidemiological

2 Layard MW. Ischaemic heart disease and spousal smoking in the national mortality followback survey. Regul Toxico Pharmacol 1995;21:180-3

3 Law MR, Morris JK, Wald NJ. Environmental tobacco smoke exposure and ischaemic heart disease: a evaluation of the evidence. BMJ 1997;315:973-80. (18 October.)

4 Steenland K, Thun M, Heath C. Environmental tobacco smoke and coronary heart disease. Circulation $1997 ; 96: 2087-8$.

\section{Passive smoking and lung cancer}

Strength of evidence on passive smoking and lung cancer is overstated

EDITOR-Hackshaw et al estimate a $26 \%$ excess risk of lung cancer (95\% confidence

Rates of misclassification of smoking in Asian women

\begin{tabular}{|c|c|c|c|c|c|}
\hline & Misclassification rate & $\begin{array}{l}\text { Hackshaw et al'; } 6 \\
\text { US/UK studies }\end{array}$ & $\begin{array}{l}\text { Lee }^{2} \text {; Japanese } \\
\text { women }\end{array}$ & $\begin{array}{l}\text { Akiyama et } \\
\mathrm{al}^{3} \text {; Japanese } \\
\text { women }\end{array}$ & $\begin{array}{l}\text { Wewers et al }{ }^{4} \text {; } \\
\text { South East Asian } \\
\text { women* }\end{array}$ \\
\hline 1 & $\begin{array}{l}\% \text { of reported non-smokers who are } \\
\text { current smokers on the basis of } \\
\text { nicotine/cotinine levels } †\end{array}$ & $2.0(33)$ & $8.8(28)$ & $9.2(11)$ & $10.9(64)$ \\
\hline 2 & $\begin{array}{l}\% \text { of all women who are current smokers } \\
\text { but report being non-smokers }\end{array}$ & 1.5 & 7.1 & 8.1 & 10.3 \\
\hline 3 & $\begin{array}{l}\% \text { of all ever smokers who are current } \\
\text { smokers but report being non-smokers }\end{array}$ & 3.1 & 21.2 & 36.7 & 57.7 \\
\hline 4 & $\begin{array}{l}\% \text { of all ever smokers who are current } \\
\text { smokers but report never having smoked }\end{array}$ & $3.1 \neq$ & 16.7 & 30.0 & 55.0 \\
\hline
\end{tabular}

Women of Cambodian, Laotian or Vietnamese origin living in Ohio.

†Urinary cotinine/creatinine $>100 \mathrm{ng} / \mathrm{mg}$ in Japanese studies, ${ }^{2} 3$ saliva cotinine $>14 \mathrm{ng} / \mathrm{ml}$ in Wewers et al. ${ }^{4}$ łHackshaw et al calculate misclassification rate 3 but wrongly apply it as if it were misclassification rate 4 .

interval $7 \%$ to $47 \%$ ) in non-smokers who live with a smoker. ${ }^{1}$ This estimate may be too high.

Their adjustment for smoking misclassiFirstly, it is based on the comparatively low misclassification rates seen in American and British populations and ignores evidence of far higher rates in Asian women (table). ${ }^{2-4}$ Secondly, it uses a new adjustment technique that takes no account of the varying relative risks from smoking in the 37 studies. Despite the fact that lung cancer has many known causes and the evidence that smoking and passive smoking are associated with higher exposure to many adverse lifestyle risk factors, ${ }^{5}$ the authors' consideration of confounding is limited to fruit and vegetable consumption. The authors dismiss publication bias, using an argument that addresses only whether such bias might explain the whole observed association. They do not even mention recall bias, and they do not discuss implications of specific weaknesses of the studies. After their inadequate downward adjustment for bias and confounding, they adjust upwards for effects of non-spousal passive exposure to smoke. Such effects are inferred indirectly from cotinine data, and the direct evidence that exposure to smoke in the workplace, in social situation, and during childhood is not associated with risk of lung cancer is ignored.

Hackshaw et al also estimate an excess risk of 19\% from passive smoking, by extrapolating from the risk in current smokers, and this may also be too high. The use of particulate matter rather than cotinine to calculate the relative exposure of passive and active smokers would reduce the excess risk estimate at least tenfold; allowance for a quadratic component to the doseresponse would reduce it further.

Hackshaw et al also create a false impression of precision by using confidence limits that take no account of the many uncertainties in the adjustment procedures used, and by emphasising the similarity of their estimates of $26 \%$ and $19 \%$. If more appropriate adjustments were used for bias and confounding and different assumptions were made in the dose-response extrapolation, both estimates could remain similar but be an order of magnitude or more lower. fication bias is inadequate for two reasons. 
Indeed, bearing in mind the possibility of a zero threshold for carcinogenesis, one might even argue that the authors have not conclusively demonstrated that passive smoking has any effect on risk of lung cancer.

Peter Lee* Independent consultant in statistics and epidemiology

Sutton, Surrey SM2 5DA

*Peter Lee acts as a consultant to the tobacco industry

1 Hackshaw AK, Law MR, Wald NJ. The accumulated evidence on lung cancer and environmental tobacco smoke. BMJ 1997:315:980-8.(18 October)

2 Lee PN. "Marriage to a smoker" may not be a valid marke of exposure in studies relating environmental tobacco smoke to risk of lung cancer in Japanese non-smoking

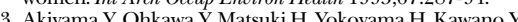
Akiyama Y, Ohkawa Y, Matsuki H, Yokoyama H, Kawano Y, Kasuga H, et al. Misclassification of smoking status comparison of questionnaire data and urinary cotinine analysis. ni: Leste GB, Lesle KJ, HuangJ, Qin Y, eds. Proceedings of the second international conference on indoor air quality in Asia. Rothenfluh, Switzerland: Indoor Ai International; 1994:319-23.

4 Wewers ME, Dhatt RK, Moeschberger ML, Guthrie RM, Kuun P, Chen MS. Misclassification of smoking status among Southeast Asian adult immigrants. Am J Respir Cril Care Med 1995;152:1917-21.

5 Thornton A, Lee P, Fry J. Differences between smokers, ex-smokers, passive smokers and non-smokers. J Clin Epidemiol 1994;47:1143-62.

\section{Risk extrapolation overestimates risk}

EDITOR-In their article on the accumulated evidence on lung cancer and environmental tobacco smoke, Hackshaw et al state that the direct $(26 \%)$ and indirect $(19 \%)$ estimates of the excess risk are similar. ${ }^{1}$ The direct risk estimate is based on a meta-analysis of 37 epidemiological studies, whereas the indirect risk estimate results from a linear extrapolation of the risk in smokers, on the basis of the concentrations of nicotine and cotinine in body fluids of smokers and nonsmokers.

We believe that the risk extrapolation presented by Hackshaw et al significantly overestimates the excess risk, mainly because they use risk and smoking dose in two different groups of smokers. They assume a relative risk of lung cancer related to smoking of about 20, which applies for heavy smokers. Seven cohort studies performed in five Western countries reported relative risks for male cigarette smokers (as a group) of 7.0 to $14.9 .^{2}$ Mean concentrations of nicotine and cotinine in body fluids, however, on which the risk extrapolation is based, are derived from male and female smokers with a wide range of smoking habits, including light smoking. Furthermore, the weighted dose ratio of $1 \%$ is not based on independent data: some groups of smokers and non-smokers appear twice or four times in the dataset. With the data listed in table $5,{ }^{1}$ we calculate a weighted average for the dose ratio of $0.8 \%$, instead of the reported $1.0 \%$.

Probably the most accurate data on serum cotinine concentrations of the general population were obtained during the third national health and nutrition examination survey in the United States.. In this study a highly sensitive analytical method with an extremely low threshold of detection for serum cotinine of $0.050 \mathrm{ng} / \mathrm{ml}$ was used. From the graphically presented distribu-

Calculated sensitivity, specificity, and biased estimate of postulated true relative risk of 2.0, obtained when using dichotomous ever/never variables for either spousal or work exposure to environmental tobacco smoke under two different assumptions regarding aetiologically relevant exposure

\begin{tabular}{|c|c|c|c|c|c|}
\hline \multicolumn{2}{|c|}{$\begin{array}{c}\text { Aetiologically relevant } \\
\text { exposure } \\
\end{array}$} & \multirow[b]{2}{*}{ Sensitivity* (\%) } & \multirow[b]{2}{*}{ Specificity* (\%) } & \multirow{2}{*}{$\begin{array}{c}\text { Biased } \\
\text { estimate } \\
\text { (relative risk)† }\end{array}$} & \multirow{2}{*}{$\begin{array}{c}\text { Prevalence of } \\
\text { aetiologically } \\
\text { relevant exposure } \\
\text { among controls (\%) }\end{array}$} \\
\hline Yes & No & & & & \\
\hline
\end{tabular}

Aetiologically relevant exposure-exposure from same source-within past 20 years

Classification based on ever exposure to smoking spouse:

\begin{tabular}{ccccccc}
\hline Men & & & & & & \\
\hline Yes & 21 & 10 & 100 & 88.37 & 1.61 & 15.3 \\
\hline No & 0 & 76 & & & & \\
\hline Women & & & & & & \\
\hline Yes & 80 & 55 & 100 & 68.02 & 1.60 & 32.5 \\
\hline No & 0 & 117 & & & & \\
\hline
\end{tabular}

Classification based on ever exposure at work:

\begin{tabular}{ccccccc}
\hline Men & & & & & & \\
\hline Yes & 64 & 24 & 100 & 44.19 & 1.69 & 55.6 \\
\hline No & 0 & 19 & & & & \\
\hline Women & & & & & & \\
\hline Yes & 125 & 50 & 100 & 60.63 & 1.67 & 44.2 \\
\hline No & 0 & 77 & & & & \\
\hline
\end{tabular}

Aetiologically relevant exposure-exposure from either source-within past 20 years

Classification based on ever exposure to smoking spouse:

Men

\begin{tabular}{ccccccc}
\hline Yes & 29 & 2 & 40.85 & 94.44 & 1.27 & 62.5 \\
\hline No & 42 & 34 & & & & \\
\hline Women & & & & & 1.16 & 63.2 \\
\hline Yes & 103 & 32 & 62.42 & 63.22 & & \\
\hline No & 62 & 55 & & & & \\
\hline
\end{tabular}

Classification based on ever exposure at work:

\begin{tabular}{ccccccc}
\hline Men & \multicolumn{1}{l}{} & & & \\
\hline Yes & 70 & 18 & 98.59 & 50 & 1.69 & 62.5 \\
\hline No & 1 & 18 & & & & \\
\hline Women & & & & & & \\
\hline Yes & 144 & 31 & 87.27 & 64.37 & 1.44 & 63.2 \\
\hline No & 21 & 56 & & & & \\
\hline
\end{tabular}

* Sensitivity and specificity calculated from each $2 \times 2$ table. $†$ Calculated using the observed sensitivity and specificity as well as the population exposure prevalence (observed prevalence among controls), assuming a true relative risk of 2.0 .

tions of the cotinine concentrations, we calculated arithmetic means of $1.05-$ $1.15 \mathrm{ng} / \mathrm{ml}$ and $180-215 \mathrm{ng} / \mathrm{ml}$ for those reporting exposure to tobacco smoke at home or work and tobacco use, respectively, yielding a dose ratio of $0.49-0.64 \%$. With the above mentioned range of the relative lung cancer risk for "average" cigarette smokers, an excess risk of 3-10\% for environmental exposure to tobacco can be extrapolated, which is three to nine times lower than the risk estimate $(26 \%)$ based on epidemiological studies. ${ }^{1}$

We therefore believe that there is a discrepancy rather than a similarity between the risk of lung cancer related to environmental tobacco smoke that is derived from epidemiological studies and that which is extrapolated from the biochemically determined exposure dose. Evaluation of the biomonitoring data on genotoxic substances for non-smokers exposed to environmental tobacco smoke results in a similar conclusion. ${ }^{4}$

Gerhard Scherer Biochemist

Wolf-Dieter Heller Statistician

Analytisch-biologisches Forschungslabor, D-80336 Munich, Germany

1 Hackshaw AK, Law MR, Wald NJ. The accumulated evidence on lung cancer and environmental tobacco smoke. BMJ 1997;315:980-8. (18 October.)

2 International Agency for Research on Cancer. Tobacco smoking. Lyons: IARC, 1986. (IARC monograph on the evaluation of the carcinogenic risk of chemicals to humans, No 38.)

3 Pirkle JL, Flegal KM, Bernert JT, Brody DJ, Etzel RA, Maurer KR. Exposure of the US population to environmental tobacco smoke. JAMA 1996:275:1233-40. 4 Scherer G, Richter E. Biomonitoring exposure to environmental tobacco smoke (ETS): a critical reappraisal. Hum Exp Toxicol 1997;16:449-59.

Accumulated evidence on lung cancer and environmental tobacco smoke

EDITOR-Hackshaw et $\mathrm{al}^{1}$ define the outcome of their study as "relative risk of lung cancer in lifelong non-smokers according to whether the spouse currently smoked or had never smoked." In fact, for the pooled variable, casecontrol studies used ever exposure to smoking cohabitant(s), whereas cohort studies mostly used ever exposure at start of follow up. The distinction is important if exposure varies and timing plays a part.

Using data from a Swedish population based case-control study, ${ }^{2}$ we simulated possible bias from misspecification of dichotomous variables regarding exposure to tobacco smoke from the spouse or at work, or both, and time since cessation of exposure. The table illustrates the potential bias introduced by using never/ever variables for exposure from the spouse or at work if only exposure from that single source during the past 20 years is aetiologically relevant, with a true relative risk of 2.0. 
After people give up smoking, much of their excess risk disappears within 10-20 years, ${ }^{3}$ and it has recently been suggested that this is also true for the risk from passive smoking. ${ }^{2}$ The simulated bias increases, particularly for women and when a spousal exposure variable is used, if relevant exposure more realistically occurs from both sources but is defined by never/ever exposure to one source (table (bottom)). Here, exposure to environmental tobacco smoke from work, spouse, or both within the relevant time is considered valid. This assumption is reasonable, as recent data show an increasing importance of exposure to tobacco smoke at work compared with exposure at home with regard to prevalence, duration, and intensity, in many countries. ${ }^{45}$ Since early studies often investigated populations with a higher prevalence of smoking among men than among women and lower occupational rates among women, increasing problems with alternative sources of environmental tobacco smoke and cessation of spousal exposure for women may partly explain why the relative risks for the pooled variable tend to decrease over time. $^{1}$

Our data also suggest that sex specific exposure patterns could contribute to sex differences in observed relative risk for a never/ ever variable. ${ }^{1}$ Although ever spousal exposure is more common among women in our study, a greater proportion of ever exposed men have been exposed recently, which is also true for exposure at work. ${ }^{2}$ Important differences in timing and sources of exposure may exist between sexes in other studies.

The pooled variable may thus be more heterogeneous than Hackshaw et al made clear. On the basis of our considerations and supported by their dose-response estimates, ${ }^{1}$ true current exposure could well convey a higher risk than the estimate reported by Hackshaw et al.

\section{Fredrik Nyberg Researcher} Göran Pershagen Professor

Division of Environmental Epidemiology, Institute of Environmental Medicine, Karolinska Institute, Box 210, S-171 77 Stockholm, Sweden

1 Hackshaw AK, Law MR, Wald NJ. The accumulated evidence on lung cancer and environmental tobacco evidence on lung cancer and environm
smoke. $B M J$ 1997;315:980-8. (18 October.)

2 Nyberg F, Agrenius V, Svartengren K, Svensson C, Pershagen G. Environmental tobacco smoke and lung cancer in nonsmokers-does time since exposure play a role? Epidemiology 1998;9:301-8.

3 International Agency for Research on Cancer. Tobacco smoking. Lyons: IARC, 1986. (IARC monograph on the evaluation of the carcinogenic risk of chemicals to humans, No 38 .

4 Pirkle JL, Flegal KM, Bernert JT, Brody DJ, Etzel RA, Maure KR. Exposure of the US population to environmental tobacco smoke: the third national health and nutrition examination survey, 1988 to 1991. JAMA 1996;275:1233-40.

5 Phillips K, Bentley MC, Howard DA, Alvan G. Assessment of air quality in Stockholm by personal monitoring of of air quality in Stockholm by personal monitoring of nonsmokers for respirable suspended particles and 1996;22:1-24.

\section{Authors' reply}

EDITOR-We accept the last footnote to Lee's table (the correction increases the adjusted estimate of lung cancer risk from 1.26 to 1.27). We disagree with his other points.

(1) Misclassification rates in the Asian data from Lee's table are implausibly high. They would make the pooled unadjusted estimate of excess risk in the 17 Asian studies $^{1}$ two to four times higher than the 20 American and European studies. But they were identical $(23 \%)$.

(2) The adjustment technique was that previously used, ${ }^{2}$ modified by Lee himself (personal communication). We used Western smoking/lung cancer relative risk estimates. Using lower estimates from countries with shorter duration of smoking would reduce the effect of the bias.

(3) Confounding factors must be linked to both lung cancer and smoking (active or passive); this leaves only diet, which cannot explain the association.

(4) Publication bias (against small negative studies) cannot be excluded completely but does not explain the excess risk because of the clear association in large studies.

(5) Cohort studies are not subject to recall bias; they yielded a similar risk estimate to case-control studies. Study quality is important but not easily characterised. Studies with different strengths and weaknesses yield strikingly consistent overall results.

(6) Categorising people by their reported exposure outside the home only is unsatisfactory; it is invalidated, variable, and likely to reflect a very small average exposure.

(7) Tobacco particulates cannot be measured in body fluids. Cotinine (from nicotine) is a validated marker of exposure in non-smokers married to smokers and shows that they have higher exposure levels both inside and outside the home.

(8) Confidence intervals indicate statistical precision; sensitivity analyses show that bias and confounding could not reasonably explain the association.

Contrary to Scherer and Heller's opinion the 20-fold relative risk between cigarette smoking and lung cancer is reasonable-it was $22.4,{ }^{3}$ and $18.5^{4}$ (second 20 year follow up). Several studies show that cotinine levels in non-smokers exposed to environmental tobacco smoke are about $1 \%$ of those in active smokers. Scherer and Heller's estimate from one study (about $0.5 \%$ ) still indicates exposure and expected risk ${ }^{5}$; it is lower probably because over $40 \%$ of "exposed" non-smokers were children.

Lee, Scherer and Heller have not considered the evidence as a whole and ignore important evidence. Non-smokers inhale carcinogens from tobacco smoke. Carcinogens in general have no threshold. Non-smokers exposed to environmental tobacco smoke show an excess risk unexplained by bias, commensurate with the extent of exposure, with a dose-response relation. The only reasonable conclusion is that breathing other people's smoke causes lung cancer.

We agree with Nyberg and Pershagen; some studies included spouses who were former smokers, which tends to underestimate risk of lung cancer.

\section{A K Hackshaw Lecturer}

M R Law Reader

NJ Wald Professor

Department of Environmental and Preventive

Medicine, Wolfson Institute of Preventive Medicine,

St Bartholomew's and the Roval London School of

Medicine and Dentistry, London EC1M 6BQ
1 Hackshaw AK, Law MR, Wald NJ. The accumulated evidence on lung cancer and environmental tobacco smoke. BMJ 1997;315:980-8. (18 October.)

2 Wald NJ, Nanchahal K, Thompson SG, Cuckle HS. Does breathing other people's tobacco smoke cause lung cancer? BMJ 1986;293:1217-22

3 Shopland DR, Eyre HJ, Pechacek TF. Smoking-attributable cancer mortality in 1991: is lung cancer now the leading cause of death among smokers in the United States? J Natl Cancer Inst 1991;83:1142-8.

4 Doll R, Peto R, Wheatley K, Gray R, Sutherland I. Mortality in relation to smoking: 40 years' observation on male British doctors. BMJ 1994:309.901-11.

5 Pirkle JL, Flegal KM, Bernert JT, Brody DJ, Etzel RA, 5 Pirkle JL, Flegal KM, Bernert JT, Brody DJ, Etzel RA, Maurer KR. Exposure of the US population to
environmental tobacco smoke. JAMA 1996;275:1233-40.

\section{The hot air on passive smoking}

Experts who evaluated studies seem not to have had relevant experience

Editor-Chapman's piece about a newspaper report on a study by the International Agency for Research on Cancer that allegedly showed that passive smoking does not cause cancer ${ }^{1}$ reminds us of a similar incident a few years ago. On 3 June 1996 Le Soir, the leading French language newspaper in Belgium, published an article carrying the following title: "Le tabagisme passif pas nocif" [passive smoking is not harmful]. This article was based on a report by Agence France Presse and indicated that six scientific experts from all over Europe had evaluated all available studies on passive smoking and concluded that no significant risk of lung cancer was associated with it.

Le Soir mentioned that the study had been sponsored by the tobacco industry and gave the names of the experts who "had accepted to perform the study on the condition that they could work without interference from the sponsors." We were struck by the presence among these experts of one professor whom we knew relatively well-not, however, for his expertise in epidemiology or smoking issues-and conducted a Medline search to find out what these experts had published in the field of epidemiology or about the effects of smoking. This gave the results shown in the table when we used "lung," "smoking," or "tobacco," as well as "epidemiol*" as (separate) search terms for the period between 1966 and 1996.

This certainly confirms the terms of BAT's memo from 1988 that Chapman mentions-namely, that scientific consultants should have "no previous record on the primary issues." We are not questioning the scientific achievements, or indeed the integrity, of these academics, but it is obvious that none of them could reasonably be considered an expert in the epidemiology of lung cancer caused by passive smoking. It would not have been difficult for journalists to find this out. We do not imply that experimental scientists have no say in assessing the impact of toxic agents on public health, but we wonder whether it is acceptable that expert panels should consist of such scientists only.

One of us seemingly fitted the profile defined in the industry's strategy and in 1990 was approached by a lawyer working for the tobacco industry. His company wanted a "well recognised university" to organise a 
Numbers of publications of members of an expert panel identified by Medline search terms

\begin{tabular}{|c|c|c|c|c|}
\hline $\begin{array}{l}\text { Author (main subject of } \\
\text { research) }\end{array}$ & $\begin{array}{l}\text { Total No of } \\
\text { publications }\end{array}$ & $\begin{array}{l}\text { Identified } \\
\text { by "Iung" }\end{array}$ & $\begin{array}{l}\text { Identified by } \\
\text { "smoking" or } \\
\text { "tobacco" }\end{array}$ & Identified by "epidemiol*" \\
\hline J Benitez (genetics) & 221 & 5 & 4 & 0 \\
\hline J R Idle (pharmacogenetics) & 159 & 12 & 1 & 24 (1 dentistry, 1 skin, 2 commentaries) \\
\hline $\begin{array}{l}\text { H Krokan (experimental } \\
\text { carcinogenesis) }\end{array}$ & 59 & 7 & 3 & 0 \\
\hline P Lohman (molecular biology) & 135 & 2 & 0 & $\begin{array}{l}1 \text { (review on contribution of molecular and } \\
\text { biochemical approaches in epidemiology) }\end{array}$ \\
\hline M Roberfroid (pharmacology) & 161 & 3 & 1 & $\begin{array}{l}1 \text { (review on role of fat, fibre, calories in } \\
\text { colon/breast cancer) }\end{array}$ \\
\hline $\begin{array}{l}\text { D R Springall (pathology, } \\
\text { histochemistry) }\end{array}$ & 102 & 39 & 2 & 0 \\
\hline
\end{tabular}

"balanced scientific debate" about environmental tobacco smoke in or near Brussels, "the centre of regulation in Europe." Apart from reservations about the costs invoked in inviting a speaker from Australia, a major stumbling block seemed to be our insistence on opening the conference with a talk addressing the effects of active smoking. The conference never took place.

Benoit Nemery Professor

Katholieke Universiteit Leuven, Department of

Occupational Medicine and Division of

Pneumology, Leuven, B-3000 Belgium

Danielle Piette Associate professor

Université Libre de Bruxelles, School of Public

Health, Health Promotion and Education Unit,

1070-Brussels, Belgium

1 Chapman S. The hot air on passive smoking. BMJ 1998,316:945. (21 March)

\section{Opinions depend on what sort of} evidence is thought most convincing

EDITOR-Chapman mocks the credulousness of journalists ("mesmerised hacks") for publicising the negative findings of the (unpublished) study of passive smoking by the International Agency for Research on Cancer (IARC) without putting it "in the perspective" of the positive findings of the large metaanalysis published last year with its "highly significant $24 \%$ excess risk of lung cancer in non-smokers living with smokers." 2

But who is being credulous? Had Chapman scrutinised that meta-analysis with any rigour he would have made two disquieting observations. Firstly, he would have noted that 18 of the 37 studies cited come from China, Japan, or Hong Kong-countries where the epidemiology of lung cancer is different from that in the West (these countries have a relatively high incidence of adenocarcinoma among women) and the strength of the causative relation between smoking and lung cancer is substantially weaker. ${ }^{3}$ Thus the inclusion of these studies cannot be justified on biological grounds.

Secondly, and more importantly, he would have noticed that the $37 \mathrm{th}$, and last, study is a massive cohort study coordinated by the American Cancer Society of nearly 250000 men and women-almost equal in numbers to the other 36 trials put together. ${ }^{4}$ This failed to show a significant relation between passive smoking and lung cancer; for good measure, $70 \%$ of the lung cancers observed in non-smokers living with smokers were of the adenocarcinoma type, which
Doll and Bradford Hill were the first to show was unrelated to smoking. ${ }^{5}$

Thus the question whether passive smoking causes lung cancer depends on what sort of evidence is the more convincing: the "negative" results of two massive studies of different design (the IARC's case-control and the American Cancer Society's cohort studies) or the "positive" results of a meta-analysis whose biologically unwarranted inclusion of many small studies from the Far East conceals the outcome of the American Cancer Society's cohort study. Any thinking doctor would no doubt plump for the former, leaving only epidemiologists such as Chapman to endorse the latter. There could be no more damning verdict on the intellectual falsehoods generated by contemporary epidemiology and the erroneous public health advice to which it gives rise.

James Le Fanu General practitioner

Mawbey Brough Health Centre, London SW8 2UD

1 Chapman S. The hot air on passive smoking. $B M J$ 1998:316:945. (21 March.)

2 Hackshaw AK, Law MR, Wald NJ. The accumulated evidence on lung cancer and environmental tobacco smoke. BMJ 1997;315:980-8.

3 Mason TJ. The descriptive epidemiology of lung cancer. In Samet J, ed. Epidemiology of lung cancer. Basle: Marce Dekker, 1994:52-5.

4 Cardenas VM, Thun MJ, Austin H, Lally CA, Clark WS, Greenberg S, et al. Environmental tobacco smoke and lung cancer mortality in the American Cancer Society's cancer

5 Doll R, Bradford Hill A. Lung cancer and other causes of death in relation to smoking. $B M J$ 1956;ii:1071-81.

\section{BAT has not tried to discredit data on} passive smoking

EDITOR-In the issue of 21 March the $B M$ carried several articles on environmental tobacco smoke, including a short item by Chapman suggesting that BAT has "tried to discredit data on passive smoking." The article claims that we knew about a major study on exposure to environmental tobacco smoke and lung cancer undertaken by the International Agency for Research on Cancer (IARC). This particular claim is accurate and should be no surprise to anyone, since the IARC has clearly noted progress on this study for some 10 years, results from three study centres have been presented at conferences, and the IARC's recent biennial report gives the overall findings of the study. ${ }^{2}$

Perhaps more surprising are press reports that Neil Collingshaw, the acting chief of the World Health Organisation's tobacco and health unit in Geneva, apparprevention study II. Cancer Causes Control 1997;8:57-64. ently did not know that such a study was being undertaken. ${ }^{3}$ Also surprising are comments from Sir Richard Doll that the full study had been submitted to two journals and rejected by both (BBC News 24, 1998 Mar 15). I assume that we will never know whether the $B M J$ considered and rejected the study and, if it did, for what reason.

All scientists interested in this area of research await the full report, although Action on Smoking and Health's website carries what it describes as the "formal abstract of the WHO paper (unpublished)" (www.ash.org.uk). This abstract reconfirms that the overall findings of the study are of a small positive association for spousal and workplace exposure, neither association being significant. This finding is consistent with results of previous research on spousal exposure, which in general show small positive associations that are not significant, and data on workplace exposure, which provide little or no indication of an increase in risk.

The "formal abstract" also reports: "Childhood exposure to ETS [environmental tobacco smoke] and exposure in vehicles and in public settings were not associated with lung cancer risk." The IARC's biennial report also suggests that there is little or no increase in the overall risk of adenocarcinoma.

The interpretation of low risk epidemiology is a matter of serious debate. If large studies, whatever they are considering, fail to find significant increases in risk then one must question whether there is a real increase in risk and, if there is, if that risk is quantifiable. To lower the standard of scientific debate simply because it concerns tobacco is unjustified.

Christopher J Proctor Head of science and regulation British American Tobacco, Staines TW18 1DY

1 Chapman S. The hot air on passive smoking. BMJ 1998:316:945. (21 March.)

2 International Agency for Research on Cancer. Biennial report 1996/7. Geneva: World Health Organisation, 1998:76-7.

3 Corcoran T. Toronto Globe and Mail 1998 Mar 17.

\section{Influenza vaccination policy and high risk subjects}

\section{Targeting and delivery should remain in general practice}

Editor-Watkins criticises the existing general practice based influenza immunisation programme. ${ }^{1}$ He declares no conflict of interest but his study was funded by the Association for Influenza Monitoring and Surveillance, which is a publicity organisation funded by manufacturers of influenza vaccines. Watkins is a member of the association's advisory board. Interestingly, the association has been deleted from the BMA's information service database.

A similar survey was conducted in this area, also in 1994-5. It was financed by the medical audit advisory group and the health authority (now South Humber Health Authority), and the results were different from those reported by Watkins. Lists of 
inpatients aged over 60 who had been discharged with heart failure, chronic lung disease, and diabetes were obtained from two local hospitals. The general practice records of each patient were then examined for details of influenza vaccination. A group at genuine high risk was identified. Overall, $68 \%$ of the patients had been immunised during the previous winter, and 15 out of 37 practices achieved a coverage of $75 \%$ or more. The conclusion was that well organised practices could do this job well. The maximum coverage achieved was $84 \%$, and general practitioners participating in the survey agreed that a hard core of patients who refuse vaccination makes any higher coverage impracticable.

Watkins found little evidence of practices using vaccination registers. However, most practices now have computer systems, all of which have a diary or recall system for immunisations.

All general practitioners know that a lot of vaccine is wasted on patients at low risk, and the current system of remuneration clearly does nothing to discourage this wastage. However, organisations such as the Association for Influenza Monitoring and Surveillance and vaccine manufacturers' other public relations efforts are also responsible for the hordes of patients who ring their general practitioner as soon as the first leaf turns brown, demanding to know when their "flu jab" will arrive.

General practitioners are better placed to assess the whole patient in terms of risk of influenza than is a public health department using central morbidity data that rapidly become outdated. Watkins' assessment of the present system is overly pessimistic because he included a lot of patients who were not really at high risk. It is also potentially biased. He suggests reform of the present system. Any such reform should build on the strength of the current general practice based system. Central purchasing might well be efficient and save money, but targeting and delivery should be left to general practice.

E Willis General practitioner

Elsham, Lincolnshire DN20 0RG

1 Watkins J. Effectiveness of influenza vaccination policy at targeting patients at high risk of complications during winter 1994-5: cross sectional survey. BMJ 1997;315:106970. (25 October.)

\section{Author's reply}

EDITOR-Willis implies that the funding of my study by the Association for Influenza Monitoring and Surveillance, a body scientifically independent from the pharmaceutical industry, represents a conflict of interest. The interests of the medical profession, the Department of Health, and the pharmaceutical industry in influenza vaccination are to promote rational use of vaccine in those who require it in line with the recommendations of the chief medical officer. My study sought to address how the current system fulfils these objectives; hence no conflict of interest existed. The findings, however, highlight the shortfall between these aims and the reality, which I believe is a much more fundamental issue.

In my study each practice was computerised and had declared its high risk population with chronic diseases before the study took place. The high risk population declared by practices and the patient records linked with the family health services authority's computer minimised bias in the numerator and denominator and was used to calculate the uptake rates of influenza vaccine in high risk groups presented in the study.

The study was carried out in general practice, with data being collected at the time of immunisation. Patients were asked how they were contacted about or why they presented for vaccination. The study showed that of the 21000 patients who presented for vaccination, over $80 \%$ had been either habituated into annual vaccination $(25 \%)$ or advised by their general practitioner $(41 \%)$ or practice nurse $(15 \%)$ on attending the surgery. The use of proactive methods such as vaccination registers, reminder letters, tagging of repeat prescriptions, etc, was limited, irrespective of whether the practice had a computer. I also found little evidence that practices with computers used them to identify and contact patients proactively for vaccination.

Willis found that patients aged over 60 with very high risk conditions discharged from hospital had an influenza vaccination rate of $68 \%$. This finding only reinforces the point that almost a third of patients at extremely high risk are unprotected from this life threatening condition by current vaccination methods. If Willis had added all high risk subjects, not just those who had been in hospital, to the South Humber sample, the overall uptake would fall to the rates reported. ${ }^{1-3}$

Current vaccine policy in adult immunisation programmes results in less than half of those who would benefit from influenza vaccine receiving it, and fewer than one in five are protected against pneumococcal disease-rates unacceptable in childhood conditions.

John Watkins Director of primary health care Gwent Health Authority, Mamhilad, Pontypool, Gwent NP4 0YP

1 Nicholson KG. Immunisation against influenza among people aged over 65 living at home in Leicestershire during the winter 1991-2. BMJ 1993:306:974-6.

2 Nguyen-Van-Tam JS, Nicholson K. Influenza immunisa tion: vaccine offer, request and uptake in high risk patient during the 1991/92 season. Epidemiol Infect 1993;111:347

Kurinczuk JJ, Nicholson KG. Uptake of influenz vaccination by patients with serious cardiac disease. $B M J$ 1989;299:367.

\section{Marketing of breast milk substitutes}

Infant food manufacturers hope code will be implemented properly

EDITOR-It is disappointing that the BMJ should give such prominence to Taylor's paper $^{1}$ as it is based on a report of the Interagency Group on Breastfeeding Monitoring that was first published 15 months ago. The paper is no more than a reworked presentation of less than $30 \%$ of the original document, some of which had already been reported in the journal. ${ }^{2}$

The timing is also disappointing in view of the announcement by the World Health Organisation in January 1998 that it is to hold consultations on infant feeding, including an initiative to identify, examine, and overcome the main obstacles to implementing the international code of marketing of breast milk substitutes in all countries. The infant food industry is happy to work with the WHO and others, but in the past the Interagency Group on Breastfeeding Monitoring has refused to meet with us and has repeatedly refused to provide the information that would allow companies to investigate the alleged contraventions.

Taylor concludes that the survey methods used in this study were successful in detecting violations of the international code and recommends that the methodology should be used in future monitoring. Yet the protocol, results, and conclusions have been severely criticised for using arbitrary definitions (J Rey, personal communication) and flawed methodology. ${ }^{3}$ We also take issue with many of the alleged violations that relate to foods not covered by the code, such as follow-on formulas (weaning milks) and weaning foods. Local regulations and codes are also ignored, even though the code states that countries should develop their own controls as appropriate to their own requirements.

In its January 1998 report to its executive board the WHO "urges that national measures adopted to give effect to the International Code include: clear definitions, which are communicated to and understood by all parties; transparent monitoring and reporting procedures to determine whether alleged violations contravene national measures; and a monitoring authority established under government responsibility." The infant food industry fully supports this recommendation and the current consultation process, which we trust will lead to proper implementation of the code by all countries, with effective, transparent and impartial monitoring of the code under government supervision.

Sarah Jacobs Executive secretary

Infant and Dietetic Foods Association, London WC2B 5JJ

Andrée Bronner Secretary general

International Association of Infant Food

Manufacturers, 75001 Paris, France

1 Taylor A. Violations of the international code of marketing of breast milk substitutes: prevalence in four countries. BMJ 1998;316:1117-9. (11 April.)

2 Wise J. Baby milk companies accused of breaching marketing code. BMJ 1997;314:167

3 Rothman J. Monitoring, compliance and surveys. Marketing and Research Today 1998 May.

Italy has initiatives regarding compliance with international code

EDITOR-Manufacturers of infant food violate the international code for the marketing of breast milk substitutes in many countries. $^{12}$ The code is meant to regulate the practices of governments and companies, but disciplines also the behaviour of health 
workers. Under article 7, companies should not offer "financial or material inducements to promote products" and health workers should not accept such inducements, and this statement was reinforced by the World Health Assembly in 1996.

Italy has a law based on the International Code and European Union directives. The prevalence of breast feeding, not well defined and probably including any breast feeding, was about $67 \%$ at 1 month and $31 \%$ at 6 months of age in $1994,{ }^{3}$ well below the WHO recommendations for exclusive breast feeding. At discharge from hospital, $68 \%$ of mothers are given free samples of formula.

A large survey, Paediatric Education Breastfeeding Research (funded by the European Union in 1995 to assess knowledge, attitudes, and practices of paediatricians on breast feeding), included in its long questionnaire this item: "Do you think it is correct for paediatricians to accept financial support from companies for research or clinical activities?" A total of 842 questionnaires were given out in 1996 at the annual congress of the Società Italiana di Pediatria. We received 406 completed questionnaires (48\%); 319 responders (38\%) answered that question. The table shows the results.

This represents the opinion of paediatricians who attend an annual congress, answer questionnaires, are interested in breast feeding, and know that there is an international code. In addition, the question (which we were not allowed to modify, as it was part of a multinational study) addressed only financial support for research or clinical activities; other types of financial support, such as participation in congresses, were not included. About two thirds of the responders were hospital paediatricians; they may be more likely than community paediatricians to know the code as the law has applied mostly in hospitals since 1995. The real level of awareness about the code and the attitude towards financial support from companies may be worse among paediatricians. To tackle this problem, the Associazione Culturale Pediatri, another association of paediatricians, is developing an internal code that will regulate the relation of individual associates and groups who apply for or are offered financial support from companies. The association will also update annually a list of companies with documented violations of the international code.

Opinion of Italian paediatricians about financial support from baby food companies

\begin{tabular}{lc} 
Answer & $\begin{array}{c}\text { No (\%) of } \\
\text { paediatricans } \\
(\mathbf{n}=\mathbf{3 1 9})\end{array}$ \\
\hline Accept financial support: & \\
\hline Unconditionally & $42(13)$ \\
\hline $\begin{array}{l}\text { From companies complying with } \\
\text { international code }\end{array}$ & $211(66)$ \\
\hline $\begin{array}{l}\text { Refuse financial support: } \\
\text { Because there is no way to control the } \\
\text { compliance of companies with } \\
\text { international code }\end{array}$ & $12(4)$ \\
\hline On moral grounds & $37(12)$ \\
\hline Uncertain & $17(5)$ \\
\hline
\end{tabular}

We thank Luis Ruiz, co-ordinator of PEBR, for the permission to publish these preliminary results.

Susanna Centuori Research fellow

Adriano Cattaneo Epidemiologist

Riccardo Davanzo Neonatologist

Tea Burmaz Research student

Menuela Del Santo Resident in paediatric

Unit for Health Services Research and

International Cooperation, Istituto per l'Infanzia,

Via dell'Istria 65/1,34100 Trieste, Italy

1 Taylor A. Violations of the international code of marketin of breast milk substitutes: prevalence in four countries. BMJ 1998:316:1117-9. (11 April.)

2 Costello A Sachdev HS. Protecting breast feeding from costello A, Sachder HS. Protecting breast feeding from breast milk substitutes. the WHO code is widely violated and needs mo98.316:1103-4.

Cont Nibali S, Castorina N, Pizzimenti G, Salomone I Siracusano MF. La pratica dell'allattamento al seno in Italia. Medico e Bambino 1998;17(1):25-9.

\section{Manufacturers have sponsored} healthcare journals

EDITOR-Breast milk substitutes remain a major cause of childhood morbidity and mortality in both low and high income countries. ${ }^{12}$ As Taylor points out, ${ }^{3}$ widespread breaching of the international code of marketing breast milk substitutes ${ }^{4}$ has prompted cautions about covert endorsements by healthcare professionals of such products. ${ }^{5}$ We are therefore concerned that sponsorship of a recent index supplement for the 1997 volume of the British Journal of Midwifery by a company that manufactures breast milk substitutes could be misconstrued as an overt endorsement of such products by healthcare organisations. This practice may in the long term be counterproductive for health education on breast feeding.

Maxwell Asante Senior registrar

Mayday University Hospital, Thornton Heath, Surrey CR7 7YE

Kathleen Asante Midwife

University Hospital of Lewisham, London

SE13 6LH

1 Golding J, Emmett P, Rogers I. Breast feeding and infan mortality. Early Human Development 1997;49(suppl):S14355.

2 Wilson A, Forsyth J, Greene S, Irvine L, Hau C, Howie P. Relationship of infant diet to childhood health: seven yea follow up of cohort of children in Dundee infant feeding study. BMJ 1998;316:21-5. (3 January.)

3 Taylor A. Monitoring the international code of marketing of breast milk substitutes: an epidemiological study in fou countries. BMJ 1998;316:1117-22. (11 April.)

4 WHO. International code of marketing breast milk substitutes. Geneva: WHO, 1981

5 Costello A, Sachdev H. Protecting breast feeding from breast milk substitutes. BMJ 1998;316:1103. (11 April.)

\section{All scientific content of the BMJ should declare authors' conflicts of interest}

EDITOR-The $B M F$ s practice of declaring any conflict of interest that the authors of papers may have encourages critical appraisal. In medical literature, however, as in politics, attempts to make public the interests of policymakers, sometimes voluntarily, seem now to require reinforcement. The $B M J$ has published a news item about the New England Journal of Medicine's failure to mention a conflict of interest for the reviewer of a book linking environmental pollutants to cancer. ${ }^{1}$

The $B M$ J risks similar revelations because most of its scientific content fails to declare authors' conflicting interests. This is particu- larly incongruous in the Editorials and Letters sections, where opinions, often on controversial subjects, are expressed without challenge (such challenge often occurs in the Education and Debate section). The editorial on the health risk of silicone breast implants is an example of this non-declaration of interests. ${ }^{2}$ Despite the media and public interest and the legal and commercial implications surrounding this issue, the authors omitted the data that presumably provoked the Food and Drug Administration's limited ban on such devices, and they dismissed other studies suggesting an association between silicone breast implants and connective disease. Yet readers of this editorial, and of a letter on the same subject in that issue, ${ }^{3}$ are ignorant of any relevant interests that the authors have. Thankfully, because the papers in the BMJ do mention conflicts, we learn that the paper that prompted the above editorial was funded, albeit indirectly, by Dow-Corning Corporation, although we are not informed that this is the manufacturer of the implants in question. ${ }^{4}$

Many readers favour the $B M /$ s editorials above the papers, hoping for an expert's evidence based review of the literature. The author, though, must select which published data to include and may also incorporate unpublished or anecdotal observations. This whole process may be coloured by subjective personal experience and preference.

There can be few reviewers whose final article differs in conclusion from their previously held opinions. A notable exception is the case of an atheistic researcher who attempted to disprove the validity of the Bible: during his studies he became so convinced by the quality and quantity of evidence that he became a Christian. ${ }^{5}$ Without such divine intervention, or at least a declaration of any conflict of interest, readers of $B M J$ editorials (and its other scientific content) will never know whether the doctrine printed depends on unbiased, evidence based criteria or, unwittingly, on conflicting interests. The BMJ must not hinder informed critique.

David F Marshall* Paediatric surgical research fellow Royal Belfast Hospital for Sick Children, Belfast

BT12 6BE

*Conflict of interest: None.

1 Josefson D. US journal embroiled in another conflict of interest scandal. BMJ 1998;316:251. (24 January.)

2 Cooper C, Dennison E. Do silicone breast implants cause 2 Cooper C, Dennison E. Do silicone breast implants ca
connective disease? BMJ 1998;316:403-4. (7 February.)

3 Collis N, Khoo CTK, Sharpe DT. Media are too eager to link silicone to disease. BMJ 1998:316:477. (7 February.) 4 Nyrén O, Yin L, Josefsson S, McLaughlin JK, Blot WJ, Engqvist M, et al. Risk of connective disease and related Engqvist M, et al. Risk of connective disease and related
disorders among women with breast implants: a disorders among women with breast implants: a
nation-wide retrospective cohort study in Sweden. BMJ 1998;316:417-22. (7 February)

5 McDowell J. Evidence that demands a verdict. San Bernardino, CA: Campus Crusade for Christ International, 1972:76.

\section{Skrabanek dedicated his life to generating scepticism}

EDITOR-In their book Follies and Fallacies in Medicine Skrabanek and McCormick cited Mencken: "for every complex problem there is a solution that is simple, direct and wrong." One of the authors, Petr Skrabanek, has been 
accused of being a consultant to the tobacco industry. ${ }^{2}$ These accusations have been dismissed as libel by those who worked with him, but as Skrabanek is dead he lacks any legal recourse.

Skrabanek and McCormick's book does not mention cigarettes. With refreshing heterodoxy it casts a critical eye over medical complacency and received wisdom. The probing arguments within it are more persuasive than didactic. If there is a school that says that medicine should not be the subject for scepticism then it is a counterproductive and blinkered one. Elsewhere Skrabanek alludes to the definitive nature of the link between smoking and lung disease ${ }^{3}-$ hardly evidence of a man hell bent on defending tobacco. His work is that of a man dedicated to thinking twice before embracing weak implications of medical research.

To hail as gospel any document from a tobacco company seems strange. Those people who do so now are those who would be slow to accept this "leak" under any other circumstances. Are they damning the dead solely to further the war with tobacco? Furthermore, the critical faculties that Skrabanek hoped to inculcate are casualties of this row in the same way that Skrabanek's reputation is a casualty

"Conflicts of interest" do not preclude valid work. But scepticism about motives is not the same as flat rejection. Context is all. In the case of Skrabanek one has merely to set the particular against the general. On one hand is the accusation that he sought, for payment, to disarm smoking's critics. On the other is a man who dedicated his academic life to generating scepticism in more than one contentious arena. If he was paid with tobacco money then he was paid for doing what he did universally and, on balance, to great benefit. How many of us can say as much? He was a remarkable teacher and a clearer thinker than many who now believe innuendo rather than the evidence of a life lived well. He taught medical undergraduates to regard the doctor, not the patient, with a jaundiced eye. That would justify him being in the pay of far worse.

There is another quotation from Mencken that springs to mind. "Puritanism. The haunting fear that someone, somewhere, may be happy." ${ }^{4}$ Conflict of interest? I was taught by Skrabanek.

Simon Mills General practitioner

27 John Dillon Street, Dublin 8, Republic of Ireland

1 Skrabanek P, McCormick J. Follies and fallacies in medicine. 2nd ed. Dublin: Tarragon Press, 1992.

2 Dyer C. Tobacco company set up network of sympathetic scientists. BMJ 1998;316:1555. (23 May.)

3 Manhattan Institute, Social Affairs Unit. Health, lifestyle and Manhattan Institute, Social Affairs Unit. Health, lifestyle and Unit, 1991.

4 Mencken HL. A Mencken chresteomathy. New York, Knopf, 1949. (Chapter 30.)

\section{Di Bella's method of curing cancer is becoming popular in Italy}

EDITOR-Abbasi has summarised well the situation concerning "Di Bella's method" for cancer. ${ }^{1}$ This situation is more serious, however, than it seemed at the meeting in London that Abbasi attended, and it might rapidly contaminate other countries, even those more cold blooded than Italy. It is a clear case of wholesale insanity despite the repeatedwarningsofoncologistsandpharmacologists. There are three new proofs of this. - The Italian constitutional court has recently decreed that the health service should reimburse the cost of Di Bella's cocktail to all the patients who cannot afford it (more than £20 a day); the health ministry has gone further, allowing it free to practically everybody. ${ }^{2}$

- A political party, heir of the former Fascist party, has embraced the cause, organising on a national scale protest marches and television talk shows, with $\mathrm{Di}$ Bella attending, sometimes with his supporters displaying banners saying, for example, "Free choice of treatment" and "Chemotherapy means death."

- Rotary International is a worldwide organisation of business and professiona leaders-supposedly wise people. But a Rotary club in Rome and another in Milan have, with press publicity, made Di Bella a Paul Harris fellow in recognition of "decades of studies and researches in oncotherapy"; even worse is the lack of official reaction from the Rotary district governors expected to supervise the club activities.

A Medline search shows that from 1966 to 1997 Di Bella has published 21 papers, but none dealing with oncology. ${ }^{3}$ It would be logical to assume that the clinical trials now in progress will give a final and decisive judgment on Di Bella's method, but this is unlikely; in fact, Di Bella has already said that these trials are void since they are not in accordance with the protocol agreed between him and the National Oncology Commission. One example of his complaints, reported by a member of this commission, is that his cocktail was lacking in vitamin $\mathrm{C}$ dissolved in mineral water. $^{4}$

The problem, involving not only Italy, is how to restore order and prevent further expansion of this crazy situation.

Rinaldo Pellegrini Consultant in clinical pharmacology

Piazzale Marengo 6, 20121 Milan, Italy

1 Abbasi K. Di Bella's miracle method. BMJ 1998;316:1617. (23 May.)

2 More patients for Italian anticancer. Scrip 1998; No 2345:3 Remuzzi G. Una presunta terapia senza basi scientifiche. Tempo Medico 1998; $40: 2$.

Scanni A. Con Di Bella è una storia senza fine. Corrier Salute 1998;10:2.

\section{New variant Creutzfeldt-Jakob disease is more common in Britain than elsewhere}

EDITOR-Although the overall incidence of Creutzfeldt-Jakob disease in the United Kingdom is similar to that in other countries in Europe, ${ }^{1}$ there is a major difference in terms of new variant Creutzfeldt-Jakob disease $^{2}: 25$ cases of new variant disease have been identified in the United Kingdom and, so far, only one outside the United Kingdom. Experimental evidence from biochemical studies ${ }^{3}$ and strain typing studies in mice $^{4}$ has indicated that the transmissible agent in new variant Creutzfeldt-Jakob disease is identical to the agent in bovine spongiform encephalopathy, although the precise mode and route of transmission are uncertain.

We and others consider a causal link between bovine spongiform encephalopathy and new variant Creutzfeldt-Jakob disease to be proved beyond reasonable doubt $^{5}$; it will be necessary to continue surveillance for all forms of CreutzfeldtJakob disease over the next few years to study future disease trends in the United Kingdom and in other countries. This will require a continuing high level of cooperation from the neuroscience community and other medical and paramedical staff and in particular the relatives of patients, without whose help the surveillance project would not be possible.

J W Ironside Senior lecturer in pathology

R S G Knight Consultant neurologist

R G Will Consultant neurologist

National Creutzfeldt-Jakob Disease Surveillance

Unit, Western General Hospital, Edinburgh

EH4 2XU

P G Smith Head of department

S N Cousens Senior lecturer

Department of Epidemiology and Population

Sciences, London School of Hygiene and Tropical Medicine, London WC1E 7HT

1 Warden J. CJD no worse in Britain than elsewhere. BMJ 1998;316:1336. (2 Mav.)

2 Will RG, Ironside JW, Zeidler M, Cousens SN, Estibeiro K, Alperovitch A, et al. A new variant of Creutzfeldt-Jako disease in the UK. Lancet 1996:347:921-5.

3 Collinge J, Sidle KCL, Meads J, Ironside J, Hill AF. Molecular an J. of $\mathrm{KCL}$ Me 'ar analysis of prion strain variation and

4 Bru ve Will RG, Io . JW, MeCond I Drummond Bruce ME, Will RG, Ironside JW, McConnell I, Drummond $\mathrm{D}$, Suttie A, et al. Transmissions to mice indicate that 'new variant CJD is caused by the BSE agent. Nature

5 Almond J, Pattison, J. Human BSE. Nature 1997;389: $437-8$

\section{Health authority was never influenced by party political pressure}

EDITOR-I am writing to comment on Mayor's recent news item about the health secretary forbidding Salford and Trafford Health Authority from continuing its planned reorganisation of children's inpatient care. ${ }^{1}$ I was chairman of Salford and Trafford Health Authority until 30 June this year, the day that the secretary of state issued his direction. I can give the $B M f$ s readers a categoric assurance that at no time did the health authority under my chairmanship (from 1994) take any decisions because of party political pressures.

Sonia D Alexander Former chairman, Salford and

Trafford Health Authorit)

1 Plowley Close, Didsbury, Manchester M20 2DB

1 Mayor S. Dobson stops reorganisation of services at Trafford hospital. $B M J$ 1998;316:161. (18 July.) 